\title{
SOCIAL ECONOMIC EQUTTY IN THE UTILIZATION OF HEIMODIALYSIS AMONG PATIENTS WITH CHRONIC RENAL FAILURE UNDER NATIONAL HEALTH INSURANCE PLAN AT DR. MOEWARDI HOSPITAL, SURAKARTA
}

\author{
Kukuh Ardian'1), Endang Sutisna Sulaeman²), Arief Suryono33 \\ ${ }^{1)}$ Masters Program in Public Health, Sebelas Maret University \\ 2)Faculty of Medicine, Sebelas Maret University \\ 3)Faculty of Law, Sebelas Maret University
}

\begin{abstract}
Background: The health care reform promulgated by World Health Organization (WHO), namely Universal Health Coverage (UHC), aims to ensure that every citizen has access to affordable and equitable health care they need with good quality. The Indonesian National Health Insurance Plan has been implemented since January 1, 2014. However, anecdotal evidence indicates that there are some inequity concerns on the use of expensive medical care, such as renal hemodialysis. This study aimed to examine social economic equity in the utilization of hemodialysis among patients with chronic renal failure under the National Health Insurance (NHI, JKN) plan.

Subjects and Method: This study was analytic observational using crosssectional design. This study was conducted at Dr. Moewardi Hospital, Surakarta, from March to April 2017. A sample of 120 patients with chronic renal failure was selected for this study by simple random sampling. The dependent variable was frequency of hemodialysis use. The independent variables were educational status, location of residence, family income, employment status (formal vs. informal), and membership status (beneficiary vs. non-beneficiary of government subsidy). The data were collected by questionnaire and were analyzed by path analysis.

Results: Higher frequency of hemodialysis use was directly associated with higher family income $(b=5.04 ; S E=2.36 ; p=0.033)$, distance $<20 \mathrm{~km}(b=-$ 1.10; $\mathrm{SE}=2.15 ; \mathrm{p}=0.610)$, working in informal sector $(\mathrm{b}=3.84 ; \mathrm{SE}=3.05 ; \mathrm{p}=$ $0.305)$, beneficiary of government subsidy $(b=-3.68 ; \mathrm{SE}=2.81 ; \mathrm{p}=0.190)$, longer duration of hemodialysis $(b=0.39 ; \mathrm{SE}=0.08 ; \mathrm{p}<0.001)$, severe condition of illness $(\mathrm{b}=46.11 ; \mathrm{SE}=2.42 ; \mathrm{p}<0.001)$, and living in urban area $(b=3.34 ; \mathrm{SE}=0.31 ; \mathrm{p}=0.147)$.

Conclusion: Higher frequency of hemodialysis use is directly affected by higher family income, distance $<20 \mathrm{~km}$, working in informal sector, beneficiary of government subsidy, longer duration of hemodialysis, severe condition of illness, and living in urban area.
\end{abstract}

Keywords: National Health Insurance, membership, hemodialysis, inequity

Correspondence: Kukuh Ardian. Masters Program in Public Health, Sebelas Maret University, Jl. Ir. Sutami 36 A, Surakarta 57126, Central Java, Indonesia. Email: kukuh.ardph@gmail.com. Mobile: +6282298148101. 